\title{
Pengaruh Terpaan Pemberitaan Sandiaga Uno di Media Online Terhadap Sikap Masyarakat (Survei di Kelurahan Tanah Baru, Depok)
}

\author{
Indri Ahsanu Amala, Rini Riyantini \\ Universitas Pembangunan Nasional Veteran Jakarta
}

\begin{abstract}
Abstrak
Media online menjadi pilihan masyarakat masa kini untuk membaca berita karena memiliki banyak kemudahan. Sebagai tahun politik, di tahun 2018 banyak bermunculan berita tentang para calon kandidat Capres dan Cawapres. Berita yang sempat menjadi sorotan media, adalah ketika tersebar video amatir Cawapres, Sandiaga Uno yang melangkahi makam tokoh Nahdatul Ulama (NU) saat berziarah. Berita tersebut mendapat tanggapan negatif dari sejumlah politisi dan tokoh agama, juga mendapat kecaman dan aksi protes dari warga Jombang, Jawa Timur. Tujuan penelitian ini adalah untuk menguku pengaruh terpaan pemberitaan Sandiaga Uno terhadap sikap masyarakat. Populasi pada penelitian ini adalah warga Kelurahan Tanah Baru sebanyak 2.978 orang, peneliti memilih responden warga Kelurahan Tanah Baru di kalangan bapak-bapak karena menurut survei yang dilakukan website Depok24jam.com, berita politik merupakan berita yang paling sering diakses dengan persentase $54 \%$ dengan karakteristik khalayak laki-laki berusia 25 sampai 55 tahun. Menggunakan metode Non Probability Sampling dan melalui teknik purposive sampling, menggunakan rumus Yamane sampel yang diambil adalah 97 orang. Berdasarkan indikator pada variable terpaan, yaitu frekuensi, durasi dan atensi serta sikap masyarakat yang diukur berdasarkan teori sikap dengan indicator kognitif, afektif dan konatif, variable terpaan pemberitaan memiliki pengaruh yang kecil terhadap variabel sikap masyarakat berdasarkan hasil perhitungan uji regresi dengan nilai $R$ Square 0,042, yang menunjukkan tidak ada pengaruh variuabel terpaan terhadap variabel sikap masyarakat.
\end{abstract}

Kata Kunci: Terpaan, Sikap, Sandiaga Uno, Teori Efek Terbatas

\begin{abstract}
Online media is the choice of today's society to read the news because it has many conveniences. As a political year, a lot of news emerged about 2018 candidates for candidates and vice presidential candidates. The news that had become the media spotlight was when there were scattered amateur Cawapres videos, Sandiaga Uno who stepped over the tomb of the Nahdatul Ulama (NU) figure during a pilgrimage. The news received a negative response from a number of politicians and religious leaders, also received criticism and protests from residents of Jombang, East Java. The purpose of this study was to determine the effect of exposure to the reporting of Sandiaga Uno on people's attitudes. The population in this study were 2,978 people from Tanah Baru Village, researchers chose respondents from Tanah Baru Sub-District among fathers because according to a survey conducted by the Depok24jam.com website, political news is the most
\end{abstract}


frequently accessed news with a percentage of 54\% with characteristics of male audiences aged 25 to 55 years. Using the Non Probability Sampling method and through a purposive sampling technique, using the Yamane formula the sample taken was 97 people. Research theory is the theory of limited media effects. The exposure to news about Sandiaga Uno uses the concept of exposure measured by 3 dimensions, namely frequency, duration and attention as well as community attitudes are also measured by 3 dimensions, namely cognitive, affective and conative. Correlation test results which are 0.087 show that there is no strong relationship between variables because they are between the coefficient intervals of 0.00 to 0.199 . The test results of the determination coefficient 0.75 indicate the low contribution of the effect of the variable $x$ to the variable $y$. Hypothesis test results $t$ count $0.855<t$ table 1.66, Ha is rejected and Ho is accepted (there is no significant effect between exposure to Sandiaga Uno's rape in online media to people's attitudes).

Keywords: Exposure, Attitude, Sandiaga Uno, Limited Effect Theory

\section{Pendahuluan}

Media online menjadi media yang paling dicari masyarakat saat ini, karena aksesnya yang praktis, cepat dan mudah. Tidak heran jika masyarakat lebih memilih media online untuk mengakses segala jenis berita, mulai dari berita ekonomi, sosial, budaya dan politik. Di ranah berita politik, muncul berita yang menjadi perhatian masyarakat Indonesia salah satunya berita mengenai para kandidat yang akan maju sebagai Calon Presiden (Capres) dan Calon Wakil Presiden (Cawapres), yaitu pasangan nomor urut satu Jokwoi-Ma'ruf dan pasangan nomor urut dua Prabowo-Sandi. Salah satu kandidat yang me njadi pemberitaan di media massa, khususnya media online adalah Cawapres, Sandiaga Salahuddin Uno atau yang akrab disapa Sandiaga Uno. Berbagai kegiatan dan aktivitas Sandiaga Uno tidak pernah luput dari sorotan media.

Kepopularitasan yang dimiliki Sandi tidak terlepas dari banyaknya pemberitaan mengenai dirinya yang tersebar melalui media online. Berita yang menjadi sorotan adalah ketika Sandiaga Uno berziarah ke makam tokoh Nahdatul Ulama, Kiai Bisri Syansuri. Dalam video berdurasi 15 detik yang ada dalam pemberitaan, terlihat Sandi melangkahi makam tokoh NU dengan kedua kakinya. Kejadian ini terjadi pada saat pasangan Prabowo-Sandi berziarah ke makam para tokoh NU di hari santri pada Senin, 22 Oktober 2018. Beberapa politisi di Indonesiapun langsung buka suara terhadap pemberitaan tersebut. Juru Bicara TKN Jokowi-Ma'ruf Amin, Ace Hasan Syadzily, merasa heran dengan perilaku Sandiaga. Ace juga memberi pernyataan dengan menyinggung gelar "santri post Islamisme" kepada Sandi. Menurut Ace, hal yang dilakukan Sandiaga sangat tidak pantas dan 
tidak etis dilakukan oleh seorang Cawapres (Sumber : detik.com). Tidak hanya berbagai komentar miring terkait perilaku Sandiaga Unoyang muncul dalam pemberitaan di media online, bahkan aksi demopun dilakukan warga Jombang, Jawa Timur pada tanggal 12 November 2018, sebagai bentuk kecaman terhadap Sandi. Warga Jombang yang mengatasnamakan "Masyarakat Peduli Ulama" berkumpul di bundaran Ringin Contong, Jombang. Koordinator aksi demo, Faizuddin Fil Muntaqobat berorasi mengecam perilaku Sandi yang dianggap tidak memiliki tata krama, tidak terpuji dan tidak sesuai dengan nilai-nilai pancasila (Sumber : TribunJatim.com).

Berdasarkan latar belakang diatas, peneliti ingin mengetahui pengaruh terpaan media online yang memuat berita mengenai Sandiaga Uno terhadap sikap masyarakat yaitu bapak-bapak warga Kelurahan Tanah Baru, Depok, Jawa Barat. Berdasarkan survei internal Relawan Binangkit Padi (Pendukung Sandi), yaitu perkumpulan para wanita, khususnya ibu-ibu pendukung Prabowo-Sandi yang dikepalai oleh Nur Asia Uno, ketertarikan warga Jawa Barat terhadap Sandiaga Uno yang disurvei di 11 Kelurahan atau Desa di wilayah menunjukan bahwa Kelurahan Tanah Baru, Depok menduduki peringkat pertama dengan persentase $42,4 \%$ dalam hal ketertarikan terhadap Sandiaga Uno. Disusul dengan Kelurahan Dago, Bandung, dengan presentase sebesar 41,3\% (Sumber : www.pikiran-rakyat.com). Alasan selanjutnya pemilih menentukan kalangan bapak-bapak Kelurahan Tanah Baru sebagai responden adalah Kelurahan Tanah Baru merupakan pengakses media online tertinggi di Kota Depok, dimana pengakses berita politiknya adalah laki-laki dengan rentang usia 25 sampai 55 tahun. Berikut grafik data persentase pembaca berita di media online di Kelurahan Tanah Baru :

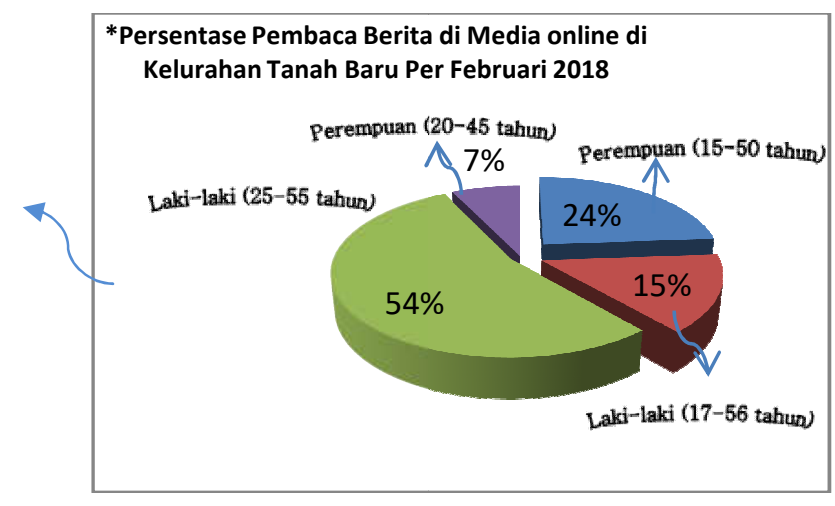

Gambar 1.

Presentase Pembaca Berita Media Online di Kelurhan Tanah Bru, Depok 
Menurut survei yang dilakukan oleh website www.depok24jam.com kelurahan Tanah Baru, Depok, Jawa Barat merupakan Pengakses media online tertinggi, dibandingkan kelurahan lainnya di kota Depok. Selain itu, berita politik merupakan topik yang paling sering diakses dengan persentase sebesar 54\%. Dari hasil survei tersebut dapat disimpulkan bahwa kalangan bapak-bapak di Kelurahan Tanah Baru memiliki karakteristik yang cocok dengan penelitian ini. Selain itu, berdasarkan data yang peneliti dapatkan dari Kantor Kelurahan Tanah Baru, jumlah penduduk laki-laki lebih banyak dari jumlah penduduk perempuan. Jumlah penduduk perempuan sebanyak 12.350 orang, sedangkan jumlah penduduk laki-laki adalah 12.551 orang. Hal ini menunjukan bahwa responden laki-laki mewakili populasi lebih besar karena jumlahnya yang lebih banyak.

Rumusan masalah pada penelitian ini adalah apakah ada pengaruh terpaan pemberitaan media online tentang Sandiaga Uno terhadap sikap masyarakat, yaitu kalangan bapak-bapak Kelurahan Tanah Baru, Depok. Berdasarkan rumusan masalah, tujuan penelitian ini untuk mengukur pengaruh terpaan pemberitaan media online tentang Sandiaga Uno terhadap sikap kalangan bapak-bapak Kelurahan Tanah Baru, Depok. Penelitian ini menggunakan pendekatan kuantitatif dengan menggunakan metode pengumpulan data melalui penyebaran kuesioner terhadap responden dengan teknik Non Probability Sampling, yaitu Purposive Sampling.

\section{Kajian Literatur}

Penelitian terkait dengan terpaan pemberitaan juga pernah dilakukan oleh Titan Armaya (2014), terkait dengan terpaan pemberitaan Jokowi terhadap tingkat kepercayaan masyarakat dan minat memilih Jokowi sebagai presiden. Penelitian selanjutnya juga dilakukan oleh Fahrina (2014) mengenai pengaruh terpaan pemberitaan politik di media online terhadap elektabilitas partai Hanura. Selanjutnya penelitian yang dilakuakn oleh Nada (2015) mengenai pengaruh pemberitaan penangkapan Bambang Widjojanto terhadap persepsi mahasiswa tentang citra KPK.

Hasil dari penelitian-penelitian tersebut mengungkap bahwa media, khususnya media online yang banyak dipakai oleh masyarakat masa kini memiliki terpaan yang memiliki pengaruh pada khalayaknya. Sehingga media online dianggap memiliki efek terpaan yang kuat bagi pembacanya. 


\section{Pembahasan}

\section{A. Karakteristik Responden}

Tabel 1. Karakteristik Responden $\mathbf{n}=97$

\begin{tabular}{|c|c|c|}
\hline Keterangan & Frekuensi (orang) & Persentase $(\%)$ \\
\hline \multicolumn{3}{|c|}{ Usia } \\
\hline $25-30$ & 22 & $22,7 \%$ \\
\hline $31-40$ & 19 & $19,6 \%$ \\
\hline $41-50$ & 54 & $55,7 \%$ \\
\hline $51-55$ & 2 & $2,1 \%$ \\
\hline & 97 & $100 \%$ \\
\hline \multicolumn{3}{|c|}{ Pendidikan } \\
\hline D3 & 16 & $16,5 \%$ \\
\hline S1 & 64 & $66,0 \%$ \\
\hline S2 & 14 & $14,4 \%$ \\
\hline S3 & 3 & $3,1 \%$ \\
\hline & 97 & $100 \%$ \\
\hline \multicolumn{3}{|c|}{ Pekerjaan } \\
\hline Karyawan Swasta & 32 & $32,1 \%$ \\
\hline PNS & 51 & $52 \%$ \\
\hline \multirow[t]{2}{*}{ Lain-lain } & 17 & $15,9 \%$ \\
\hline & 97 & $100 \%$ \\
\hline
\end{tabular}

Sumber: hasil pengolahan data 2018

Populasi pada penelitian ini yaitu warga Tanah Baru berjenis kelamin laki-laki dengan rentang usia 25 sampai 55 tahun yang berjumlah 2.978 orang dengan menggunakan rumus yamane maka sampel pada penelitian ini berjumlah 97 orang. Berdasarkan tabel 1, diketahui bahwa responden yang terlibat dalam penelitian ini sebanyak 97 orang dengan jumlah responden pada kategori usia, responden terbanyak adalah usia 41-50 tahun dengan frekuensi 54 orang dan persentase 55,7\%. Berdasarkan hasil tersebut responden pada penelitian ini paling banyak berusia 41 sampai 50 tahun, karena wilayah Kelurahan Tanah Baru, khususnya Perumahan Beji Permai dan sekitarnya dimana peneliti menyebarkan kuesioner sebagian penduduknya merupakan pekerja kantoran atau karyawan yang hampir menginjak usia pensiun, baik yang bekerja di kantor swasta maupun negeri. Selain itu, rentang usia 25 sampai dengan 55 tahun memang memiliki frekuensi paling banyak diantara warga Kelurahan Tanah Baru, yaitu 
mencapai 5.903 orang, dibandingkan dengan usia warga yang lebih muda dengan rentang usia 19 sampai 24 tahun hanya mencapai jumlah 3.531 orang. Selisih nilai jumlah penduduk yang berusia 25 sampai 50 tahun dengan yang berusia 19 sampai 24 tahun cukup besar, yaitu 2.372. Sedangkan hasil terendah adalah rentang usia 50-60 tahun dengan persentasi hanya $2,1 \%$. Hal ini dikarenakan memang jumlah orang lanjut usia atau lansia paling sedikit berdasarkan pada tabel jumlah warga kelurahan Tanah Baru, yairu hanya sebanyak 2.404 orang.

Dalam kategori pendidikan, responden terbanyak adalah yang memiliki pendidikan terakhir S1 dengan frekuensi 64 orang dan persentse $66 \%$. Dari hasil tersebut dapat disimpulkan bahwa responden pada penelitian ini paling banyak memiliki pendidikan terakhir S1, hal ini karena wilayah Kelurahan Tanah Baru, Depok yang sangat strategi dan memiliki akses yang mudah ke beberapa perguruan tinggi swasta maupun negeri seperti Universitas Indonesia (UI), Universitas Pancasila (UP), Universitas Gunadharma dan Universitas Pembangunan Nasional (UPN) "Veteran" Jakarta. Beberapa perguruan tinggi tersebut tentunya memiliki kredibilitas dan reputasi yang baik di kalangan masyarakat. Alasan selanjutnya, latar belakang pendidikan S1 paling tinggi frekuensi dan persentasenya adalah karena daya saing di dunia kerja semakin tinggi, hal itu menuntut setiap masyarakat untuk mengejar gelar sarjana sebagai modal persaingan di dunia kerja, selain itu Kelurahan Tanah Baru memiliki posisi strategis yang dekat dengan perbatasan wilayah DKI Jakarta, sehingga banyak penduduknya yang memilih bekerja di Jakarta, maka dari itu latar belakang pendidikan yang tinggi juga dibutuhkan dalam mengikuti tuntutan dunia pekerjaan, khususnya di daerah ibu kota. Perkembangan Kota Depok juga menjadi alasan dimana Kota Depok sudah memiliki akses semakin maju, sehingga memungkinkan warganya juga untuk ikut berkembang dalam bergbagai aspek dan bidang kehidupan.

Selanjutnya, yaitu kategori pekerjaan. Alasan peneliti memilih kategorisasi pekerjaan adalah karena lingkungan pekerjaan biasanya juga dapat mempengaruhi sikap selektif seseorang dalam menerima informasi, khususnya dalam menerima terpaan pemberitaan media online. Di kategori Pekerjaan, urutan pertama dengan frekuensi terbanyak yaitu, 51 orang dan persentase 52\% adalah PNS (Pegawai Negeri Sipil). Hal ini dikarenakan minat wirausaha warga Kelurahan Tanah Baru yang masih sangat minim, sehingga beberapa kali diadakan penyuluhan bertema wirausaha yang digalangkan oleh Walikota yang dilakukan di beberapa RW (Rukun Warga) di Kelurahan Tanah Baru. Minat menjadi PNS lebih besar sehingga kebanyakan dari warga masih memilih PNS sebagai profesi utama. Di urutan kedua, karyawan swasta dengan frekuensi 32 orang dan persentase $32,1 \%$. Selain PNS, Karyawan swasta juga menjadi profesi yang masih sangat 
diminati oleh warga Kota Depok, hal ini didasarkan pada survei depok24jam.com terkait penumpang KRL Commuter Line di beberapa stasiun di Kota Depok, sebagian besar penumpang KRL Commuter Line adalah karyawan swasta dengan kantor yang terletak di daerah ibu kota. Selanjutnya kategorisasi lain-lain yaitu, profesi diluar PNS dan karyawan swasta dengan frekuensi 17 orang dan persentase 15,9 \%. Pada proses penyebaran kuesioner di lapangan yang masuk dalam kategori lain-lain diantaranya adalah wiraswasta kalangan menengah kebawah.

Berdasarkan hasil analisis deskriptif ketiga kategorisasi responden, didapatkan hasil yaitu, pada kategorisasi usia 40-50 tahun terbanyak dengan frekuensi 54 orang dan persentase 55,7 \%, pada kategorisasi pendidikan terakhir S1 (Strata 1) terbanyak dengan frekuensi 64 orang dan persentse 66 $\%$ dan pada kategorisasi pekerjaan PNS terbanyak dengan frekuensi 51 orang dan persentase $52 \%$. Maka dapat disimpulkan bahwa sebagian besar responden dalam penelitian ini termasuk dalam rentang usia 40 sampai 50 tahun dengan latar belakang pendidikan S1 serta berprofesi sebagai PNS.

\section{B. Analisis Inferensial}

Analisis inferensial pada penelitian ini dilakukan dengan menggunakan uji regresi, serta uji hipotesis.

\section{1) Uji Regresi}

Tabel 2. Hasil Uji Regresi

\begin{tabular}{|l|c|r|r|r|}
\hline & Model Summary \\
$\mathrm{M}$ & $\mathrm{R}$ & $\begin{array}{c}\mathrm{R} \\
\text { Square }\end{array}$ & $\begin{array}{c}\text { Adjusted R } \\
\text { Square }\end{array}$ & $\begin{array}{c}\text { Std. Error } \\
\text { of the } \\
\text { Estimate }\end{array}$ \\
\hline 1 & $.206^{\mathrm{a}}$ & .042 & .032 & 3.954 \\
\hline
\end{tabular}
Sumber: data olah SPSS

Dari tabel 2 diatas, hasil uji regresi menunjukkan nilai $R$ Square sebesar 0,042. Dari hasil tersebut dapat disimpulkan bahwa pada penelitian ini tidak ada pengaruh terpaan pemberitaan Sandiaga Uno di media online terhadap sikap masyarakat, kalangan bapak-bapak Kelurahan Tanah Baru, Depok.

\section{2) Uji Hipotesis}

Uji $\mathrm{T}$ atau uji hipotesis dilakukan untuk mengetahui signifikasi koefisien antara Variabel X dengan Variabel Y. Dasar dari pengambilan keputusan adalah membandingkan $t$ hitung dengan $t$ tabel:

a) Jika $t$ hitung $<t$ tabel maka Ho diterima dan Ha ditolak

b) Jika t hitung $>\mathrm{t}$ tabel maka Ho ditolak dan Ha diterima 


\section{PEkRSERES SI}

Volume 1/Nomor 2 Januari - Juni 2019

ISSN 2656-050X

$$
t=r \frac{\sqrt{n-2}}{\sqrt{1-r^{2}}}
$$

Keterangan:

$\mathrm{t}=$ signifikasi koefisien korelasi

$\mathrm{r}=$ nilai koefisien korelasi variabel $\mathrm{X}$ dan $\mathrm{Y}$

$\mathrm{n}=$ jumlah responden atau sampel

$$
\begin{aligned}
& t=\frac{0,087 \sqrt{97-2}}{\sqrt{1-0,087^{2}}} \\
& t=\frac{0,087 \sqrt{95}}{\sqrt{1-0,0075}} \\
& t=\frac{0,087 \times 9,7467}{\sqrt{0,9925}} \\
& \mathrm{t}=\frac{0,8479}{0,996} \\
& t=0,851
\end{aligned}
$$

Berdasarkan perhitungan diatas, diperoleh t hitung yaitu sebesar 0,851. Dari hasil korelasi antara variabel $X$ (terpaan pemberitaan Sandiaga Uno di media online) dengan variabel Y (sikap masyarakat), t hitung $(0,851)$ $<\mathrm{t}$ table 1,660 maka Ha ditolak dan Ho diterima (tidak ada pengaruh). Dengan demikian terpaan pemberitaan di media online terkait Sandiaga Uno tidak memiliki pengaruh terhadap sikap masyarakat.

\section{Simpulan}

Berdasarkan hasil penelitian tidak terdapat pengaruh antara pemberitaan mengenai Sandiaga Uno di media online terhadap sikap masyarakat, khususnya kalangan bapak-bapak Kelurahan Tanah Baru, serta pembahasan yang didapat dari penyebaran kuesioner kemudian data tersebut diolah dengan SPSS versi 2.3, maka penulis menyimpulkan:

Tidak terdapat pengaruh antara pemberitaan mengenai Sandiaga Uno di media online terhadap sikap masyarakat, khususnya kalangan bapakbapak Kelurahan Tanah Baru dengan nilai $R^{2}$ sebesar 0,042. Kemudian hasil uji hipotesis yang diperoleh yaitu dengan $t$ hitung $(0,851)<\mathrm{t}$ tabel 1,660. 


\section{ISSN 2656-050X}

\section{Referensi}

Azwar, Saifuddin.2015.Sikap Manuisa Teori Dan Penerapannya.Yogyakarta : Pustaka Pelajar

Barran, Stanley J. Dan Davis, Dennis, K.(2009).Mass Communications Theory : Foundations, Ferment, and Future.Boston : Wadsworth Cengange Learning

Creswell,J.W.(2010).Reseacrh Design : Pendekatan Kualitatif, Kuantitatif dam Mixed. Yogyakarta : Pustaka Pelajar

Mcquail, D.(2011).Teori Komunikasi Massa.Jakarta : Salemba Humanika

Romli, Asep Syamsul M.(2012.).Jurnalistik Online Panduan Praktis Mengelola Media Online.(Bandung : Nuansa Cendikia)

Sugiyono.(2015) .Metode penelitian kuantitatif kualitatif dan $R \& D$. Bandung: alfabeta

Armaya, Titan.(2014).Terpaan Pemberitaan Media Massa Dan Tingkat Kepercayaan Masyarakat Pada Kompetensi Jokowi Sebagai Pemimpin Terhadap Minat Masyarakat Memilih Jokowi Sebagai Capres.Ilmu Komunikasi.Fakultas Ilmu Sosial Ilmu Politik.Universitas Diponegoro.

Ilhami F.,Santoso Hedi P. \& Setyabudi D.(2014).Pengaruh Terpaan Pemberitaan Politik Di Media Online Dan Terpaan Pesan Iklan Kampanye Politik Di Media Televisi Terhadap Elektabilitas Partai Hanura.Jurnal Ilmu Komunikasi

Online :

Hantoro, Juli.(15 November 2018).Peneliti LSI: Sikap Sandiaga Melangkahi MakamBerdampakElektoral.https://www.google.com/amp/s/pilpres.te mpo.co/amp/1146412/peneliti-lsi-sikap-sandiaga-melangkahi-makamberdampak-elektoral. Diakses pada 16 November 2018 pukul 08:15 WIB.

Kurnia, Tommy.(26 Jul 2018).Masuk Daftar Orang Terkaya RI, Harta Sandiaga Uno Turun $R p$ 2,8

Triliun.https://m.liputan6.com/amp/3600634/masuk-daftar-orangterkaya-ri-harta-sandiaga-uno-turun-rp-28-triliun. Diakses pada tanggal 15 November pukul 15:17 WIB 
Liputan6.com.(13 November 2018).PKB: Tidak Pantas Sandiaga Langkahi Makam Pendiri NU.

https://www.google.com/amp/s/m.liputan6.com/amp/3690730/pkbtidak-pantas-sandiaga-langkahi-makam-pendiri-nu. Diakses pada tanggal 15 November 2018 pukul 16:02 WIB

Siregar, Raja Adil.(13 November 2018).Sandiaga Uno Minta Maaf Lagi soal Langkahi Makam https://m.detik.com/news/berita/d-

4299902/sandiaga-uno-minta-maaf-lagi-soal-langkahi-makam.Diakses pada 15 November pukul 15:22 WIB.

Tribunnews.(12 November 2018).Didemo karena Langkahi Makam Pendiri NU, Tim Prabowo-Sandi Sebut Ada

Politisasi.https://www.google.com/amp/m.tribunnews.com/amp/region al/2018/11/12/didemo-karena-langkahi-makam-pendiri-nu-timprabowo-sandi-sebut-ada-politisasi.Diakses pada 16 November 2018 pukul 08:33 WIB

Zulkarnain, M.(10 November 2018).Survey Internal Binangkit Menangkan Sandi di Jawa Barat.

https://www.google.com/amp/pikiranrakyat.com/amp/regional//surveyinternal-binangkit-menangkan-sandi-di-jawa-barat. Diakses pada tanggal 16 November 2018 pukul 09:01 WIB

Deddy, Wiranto (4 Maret 2018). Modernisasi di Kelurahan Tanah Baru : Menguak Berbagai Informasi Melalui Media Online. https://www.google.com/amp/depok24jam.com/amp/regional//moderni sasi di kelurahan tanah baru-menguak-berbagai-informasi-melaluimedia-online. Diakses pada tanggal 30 Desember 2018 pukul 20:06 WIB

Deddy, Wiranto (5 Maret 2018). Warga Kelurahan Tanah Baru Punya Literasi Tinggi Terhadap Media Online https://www.google.com/amp/depok24jam.com/amp/regional//wargakelurahan-tanah-baru-punya-literasi-tinggi-terhadap-media-online. Diakses pada tanggal 30 Desember 2018 pukul 20:11 WIB 